\title{
Solid Intentions: \\ An Archival Ethnography of Corporate Architecture and Organizational Remembering
}

\author{
Stephanie Decker \\ Aston Business School \\ Aston Triangle \\ Birmingham B4 7ET \\ s.decker@aston.ac.uk
}

\begin{abstract}
Research on organizational spaces has not considered the importance of collective memory for the process of investing meaning in corporate architecture. Employing an archival ethnography approach, practices of organizational remembering emerge as a way to shape the meanings associated with architectural designs. While the role of monuments and museums are wellestablished in studies of collective memory, this research extends the concept of spatiality to practices of organizational remembering that focus on a wider selection of corporate architecture. By analyzing the historical shift from colonial to modernist architecture for banks and retailers in Ghana and Nigeria in the 1950s and 1960s on the basis of documents and photographs from three different companies, this article shows how archival sources can be used to untangle the ways in which companies seek to ascribe meaning to their architectural output. Buildings allude to the past and the future in a range of complex ways that can be interpreted more fully by reference to the archival sources and the historical context of their creation. Social remembering has the potential to explain why and how buildings have meaning, while archival ethnography offers a new research approach to investigate changing organizational practices
\end{abstract}

Keywords: Organizational remembering - archival ethnography - organizational space - modernist architecture- history 


\section{Introduction}

Despite a growing interest in spatiality and architecture in organization studies, research in this area has been largely separate from studies of organizational remembering. Work on collective memory, however, has emphasized the importance of specific sites. This goes back to the pioneer of social memory studies, Maurice Halbwachs, who held that memory was determined by membership of specific groups, and that this required a spatial framework to maintain stable identities. Even though the proponents of social remembering in organizations such as Rowlinson et al. (2010) have criticized mainstream organization memory studies for their narrowly managerialist understanding of memory, Walsh and Ungson (1991: 66) listed the physical environment as one of the 'storage bins' of organizational memory. Thus, when considering corporate architecture and space, there is no getting away from memory.

A wide variety of corporate buildings, not just museums or monuments, are significant for organizational remembering. Organizational memory is frequently spatially represented as well as enacted. Why are collective memories and identities so often tied to significant sites and monuments? Conversely, why do we think we can vicariously experience a time long gone or the culture of a place far away through its cultural productions, most importantly by experiencing their spaces and places? It is because these artifacts are the main idiom of museums and re-enactments, and similarly feature in organizational life. What is the role of corporate architecture and the built environment in social practices of remembering in organizational life?

This article contributes to the literature on organizational memory by investigating the role of architecture and space. Places such as corporate headquarters or other landmark buildings can serve as potentially powerful crucibles that merge individual experiences and memories into a collective whole, and provide visual and physical prompts to reinforce a sense of belonging to a mnemonic community (Zerubavel, 2003: 4) that is too large to allow immediate knowledge of all its members. Existing research into architecture and spatiality has not considered the important role of collective 
memory in giving meaning and intention to buildings, even though the importance of social conventions is often noted (Fayard and Weeks, 2007). Frequently, architectural styles are interpreted as telling stories in and of themselves (Yanow, 1995, 1998), and serve to emphasize the importance of the architect's intentions. But the meanings we commonly associate with many classical or modern building styles are heavily embedded in the narratives that form the basis of social remembering. Architecture becomes meaningful through a shared understanding that is based on collective memory, thus creating interpretations that transcend individual experience. This is communicated in a variety of ways to allow the observer to make sense of the symbolic features of the building, regardless of whether this was intended by the architect or imposed by the perceptions of subsequent generations. The way people interpret buildings is thus mediated by collective memory, and this memory is constantly evolving. Although the built environment gives observers a sense of stability, the way people experience architecture is embedded in a specific time and context. Unravelling how buildings can allude in complex ways to the past as well as the future can be difficult to achieve with the standard research methods in organization studies, and historical methods based on archival research are better suited to investigating memory and spatiality.

Hence this article proposes a novel approach - archival ethnography - based on the organizational archives of three British multinationals (Barclays Bank, Standard Chartered Bank, and Unilever) in a context that has not featured in organizational research: two West African countries (Ghana and Nigeria) at the time of decolonization and early independence (1950-1970). This was an enormously dynamic time period which witnessed significant institutional, social and organizational changes. These transformations were considered desirable, and the architecture of this period was designed not to give a sense of stability, but rather to embody a progressive vision of the future. In fact, the companies researched in this article used modernist architecture and future-oriented narratives to engender a form of organizational forgetting of their involvement in the colonial past of these countries. 


\section{Collective Memory and Organizational Space}

Modernist architecture in West Africa was an important, yet frequently overlooked, phenomenon because of the symbolically charged relationship between the adoption of this new style and the independence of former colonies (Hess, 2000; Kultermann, 1963; Kultermann, 1969). It was conceptually and semantically linked to the notion of modernity (Scott, 1998; Molnár, 2013; Molnár, 2005), and modernism's appeal clearly lay in its aspirational aspect. Modernity remains a deeply fraught concept in the African context, because the continent was, at least since the imposition of colonial rule, constructed as the West's 'traditional other' in the late nineteenth and early twentieth centuries (Ranger, 1983: 247-252), a dark continent that by contrast made colonialism appear enlightened (Probst et al., 2001). Thus the widespread adoption of modernist architecture in the nationalist period as shown by Hess (2000) symbolically enacted a new era for Africa's political and economic development, and companies needed to very visibly associate themselves with the emerging national identity.

The notion of modernity is central for understanding institutional change in Africa, and it is particularly relevant for the case of modernist architecture. Collective memory was being reshaped around the symbolic "new beginning" of independence, a watershed that separated the traditional, colonial past from the vision of a progressive and thoroughly modern state. The past as well as the future were narratively constructed, but in these semi-literate societies, the symbolic significance of modernist architecture that very visibly demonstrated that "something was different" (Frandsen et al., n.d.: 35) cannot be overestimated. Eric Hobsbawm and Terence Ranger similarly argue in the Invention of Tradition (1983) - highly influential in the humanities but almost unknown in organization studies - that the past in the sense of a tradition, or a collective memory, is constructed through temporal narratives. ${ }^{1}$ Even though they focus more on claims of invented antiquity, Hobsbawm (1983: 2) also argued that progressive movements define themselves by creating their own relevant past through defining a 'start date'. Architecture and narrative come together when 
organizations practice social remembering to change their corporate image by creating new memories, at the expense of old ones. This article shows that architecture can refer in complex ways to the past as well as the future in order to engage with important external audiences on a local, national and even international level.

Nevertheless, this connection between memory and spatiality has remained largely underresearched and under-conceptualised, even though the pioneer of social memory studies, Maurice Halbwachs, viewed space as necessary for all forms of social remembering: "every collective memory unfolds within a spatial framework (Halbwachs, 1980 [1950]: 6-7)." Space matters to collective memory, and so do its representations and interpretations: the symbolic meanings that society attaches to buildings must be considered as a totality. He illustrates this by the practice of pilgrimages: "Not every believer can make a pilgrimage to Jerusalem and contemplate with his own eyes the holy places. But it is enough to picture them and know they continue to exist" (Halbwachs, 1980 [1950]: 14). Halbwachs also acknowledges the temptation to view the material world as if it told its own stories, "as if the style of furniture, the manner of décor and arrangement, were some language to be interpreted. [...] While they do not speak, we nevertheless understand them because they have a meaning easily interpreted" (Halbwachs, 1980 [1950]: 1). Yet how do we interpret the built environment, and how do we know that others share our interpretations, however imperfectly?

Spatiality is narratively constructed, and the interpretations of what these buildings may signify depend on the shared memory of a group of people. Eviatar Zerubavel (2003) coined the term mnemonic communities for these groups. While he is mostly concerned with large-scale units such as the nation, he does not view companies as substantially different in their mnemonic practices. His approach seeks to connect memory with narrative: stories of progress or decline. He is also interested in whether these stories construct continuity, or break the flow of history into discontinuous episodes (Zerubavel, 2003: 14-18, 82-100), which has strong affinities to the 
"invention of tradition" literature. Organizational stories that focus on temporal sequences have been identified by David Boje (2008) as "chronotopes"; however narrative scholars have not usually considered the role of these tales for the making of memories. Instead they have focused on a variety of related issues, such as legitimacy or organizational identity (Sillince and Brown, 2009; Rhodes and Brown, 2005; Humphreys and Brown, 2002; Brown et al., 2010; Brown et al., 2009; Brown, 2006; Golant and Sillince, 2007).

In their work on organizational identity and forgetting, Anteby and Molnár (2012) combined the interview-based approaches common in identity research with a focus on the making and remaking of rhetorical history (Suddaby et al., 2010b). They emphasize the importance of forgetting for the maintenance of organizational identities over time. Moreover, forgetting is what makes memory different from history (Rowlinson et al., 2010: 74). Halbwachs distinguished the two on the basis of relevance: history is a remembered past to which a community has lost an "organic" connection, while the collective memory contains the active past that remains of importance for group identities (Olick, 2001: 7).

Rowlinson et al. (2010) for example highlight the interpersonal and constructivist nature of organizational remembering but they criticize that the dominant research methods such as interviewing have implicitly created a concept of 'collected' memories, which does not fully account for the socially constructed nature of collective memory (Rowlinson et al., 2010: 72). This recent work on collective memory and rhetorical history acknowledges the importance of Halbwachs' contribution. Nevertheless there has not been any significant engagement with spatiality so far, despite the importance of "imaginatively re-enacting memories" (Halbwachs, 1992: 24). Any reenactment may have not only a narrative but also a spatial context, such as corporate anniversary celebrations. Here Foster et al. (2011: 115) suggest that "exploring questions of organizational space and architecture could shed some light on which forms of social memory are more malleable and, perhaps, easier to leverage than others." Rowlinson et al. (2010) have similarly argued that 
organizational remembering would benefit from researching not only the products (narratives and imagery in various forms) but also the sites (monuments, artifacts and rituals) of social remembering. The creation of rhetorical histories (Suddaby et al., 2010a; Delahaye et al., 2009; Suddaby and Foster, n.d.) is important in this context, because companies can exert significant influence over these forms of social remembrances, especially through their buildings whose design and uses they can control. Foster et al. (2011: 105) believe that social memory can be leveraged like an asset in order to achieve greater legitimacy vis-à-vis "external stakeholders of the firm with whom the appropriated memories resonate."

The reason for this apparent disconnect between the literature on memory and spatiality may be due to the fact that memory is perceived as a dynamic and temporal concept, while space is often viewed as almost divorced from any change in time. This is evident in the discussion by Karen Dale and Gibson Burrell (2008: 31), who argue, citing Dovey (1999: xii), that "space is deployed to stabilize time." This implies that space has an inherent stability; however the meanings associated with the built environment change with time like anything else.

But once space is considered in its narrative embedment, it is not at all clear why architecture should exclusively embody stability regardless of context. Certainly architects view their creations as dynamic (Arnhem, 1977), while in organizational history Marc Mentzer (2010: 432) argued that "the essence of the modern aesthetic is that one no longer looks to the past to convey legitimacy on the present", which means that certain architectural styles have connotations of social and political radicalism. Indeed, Mauro Guillén (2006) argued that the widespread adoption of modernist architecture around the globe was a sign of a new ideology, even though I would question whether his disciplinary origin in management studies leads him to exaggerate the global influence of scientific management. The highly influential anthropologist James C Scott (1998), for example, saw modernism in more general terms as a comprehensive attempt at social engineering. Wholesale stylistic changes of the built environment can serve as turning points for narratives of discontinuity 
(Zerubavel, 2003: 82-85), by symbolically creating watershed moments that are foundational for progressive movements (Hobsbawm, 1983).

Nevertheless these temporal aspects of spatiality have not featured prominently in what is now a growing body of literature on organizational space (Beyes and Steyaert, 2012; Burrell and Dale, 2003; Dale and Burrell, 2008, 2010; Fayard and Weeks, 2007; Kornberger and Clegg, 2004). What has been referred to as a minor spatial turn has culminated so far in a special issue in Organization Studies (O'Doherty et al., 2013). This engagement with spatiality ranges from Fayard and Weeks' (2007) investigations of how people negotiate the physical and social aspects of space, to Burrell and Dale's (2003) analysis of how architecture can facilitate the creation of new categories of people.

While Burrell and Dale's extensive work on organisational architecture does justice to its complexities, they occasionally oversimplify architectural meaning as zeitgeist: "Architecture tells us about the ideas of a particular time and space, expressed materially (Dale and Burrell, 2008: 26)." This comes close to a semantic approach to architecture that views buildings as a form of spatial language that can be deciphered like any other form of speech, and is perhaps better exemplified by the work of (Yanow (1995); Yanow (1998)), as well as van Marrewijk and Yanow (2010), Panayiotou and Kafiris (2011) and Frandsen, Hiller, Traflet, \& McGoun (2013).

Those who do not follow a semantic approach often focus on the intentions of architects when trying to understand the interpretations of architectural meanings. This is particularly true for Guillén's work, who tried to prove the connection between modernism and scientific management by focusing on the influence of engineering on the architectural profession (Guillén, 1997; Guillén, 2006). This has been disputed for Britain by Alistair Mutch (2011), who showed for one seminal modernist factory, the Boots Wets building in Nottingham, that even though ideas from materials engineering may have been important to its architect, this was in no way connected to scientific management, or any great influence of modernist ideology in general. Mentzer (2010), however, 
accepts Guillén's argument, and, in contrast to either Guillén or Mutch, he is far more interested in the motivations that drove the architects' clients to adopt a more functionalist design.

Yet these approaches appear to be the target of criticisms that the performative nature of space is tamed into mere representation (Massey, 2005: 20; Dale and Burrell, 2008: 5; Beyes and Steyaert, 2012: 49). Nevertheless is seems too simplistic naive-to imply, like Timon Beyes and Chris Steyaert (2012), that there can be a "raw" experiential encounter with space that is free of any narrative preconceptions. This is akin to claims of taking an a-theoretical inductive stance in relation to research, as if the historical context of a society did not matter.

While history has had a long tradition of researching buildings and artifacts, the discipline has similarly experienced a spatial turn, which has, however, remained strongly influenced by concepts from cultural history; see for example the recent special issue in History \& Theory (Kümin and Usborne, 2013). What links both research traditions is the importance of the contribution of Henri Lefebvre, who argues that The Production of Space (1991) takes place simultaneously on three different levels: planned and thus intentionally symbolic; lived and thus an experience of what the space offers an individual; finally socially constructed by a group of people who negotiates the associated rules and practices of using space. Yet historical theorists like William Whyte (2006: 154)Whyte (2006), in his discussion of how the meaning of buildings can be deciphered, make muchare far less of interested in this distinction between representational and performative approaches to space than Beyes and Steyaert (2012), for example. Instead, he employs Lefebvre's notion of three types of space - planned, lived, and socially constructed - as the basis for his notion of transpositions. This refers to how architecture is transferred between different media: blueprints, photographs, maps, descriptions and actual buildings. In many ways these differences are a direct result of the different research methods employed by historians and organisation scholars (Bernardi and Greenwood, 2014). 


\section{Archival ethnography}

West African cities look different from their European and North American counterparts, but modernist bank branches or office blocks often stand out for visitors due to the familiarity of some of their geometric designs. I became intrigued by the many examples of modernist architecture on my first research trip to Accra (Ghana) in 2004, and on a subsequent visit in 2006 to Accra, Cape Coast (Ghana) and Lagos (Nigeria) I began to investigate these buildings more closely. Interviews with two architects ${ }^{2}$ who worked for architectural practices that were quite significant in terms of their contribution to tropical modernism confirmed my impression that this style was influenced by the ideas and political values of their time. But my encounter was far more personal during these trips and follow-up visits in 2009 and 2010, because I usually stayed in one of the longest serving hotels in the city, the Avenida Hotel, and worked in the nearby National Archives. The Avenida Hotel was one of the few private hotels already operating in the 1950s, and is located in a colonial building that used to be home to a well-known Ghanaian nationalist, Kojo Thompson. The hotel has a modernist annex, which was displayed in a major architectural book on Africa's "new architecture" (Kultermann, 1963: 16, 122), and designed by one of the leading architects of tropical modernism in Ghana, Kenneth Scott. Having stayed in the annex many times, it is fair to say that it has not stood the tests of time and climate well. Without regular maintenance hardly any of the rooms have hot water, the ground floor rooms have wet walls, while the upstairs rooms are infested with mice. Although the colonial building which forms the main part of the hotel also suffers from neglect and is far older, in general it seems to have aged better.

The national archives building in Accra (officially "Public Records Administration and Archives Department") is another example of how tropical modernism was adapted to the climate - in contrast to the annex this design was implemented before air-conditioning units became more widely available. The archival search room is located upstairs in the long shallow section of the building with louvered windows on both sides that can be opened to allow a breeze to cool down 
the building. Nowadays it has been fitted with air-conditioning units, but these are not always in use, because of a lack of electricity due to a power failure or scheduled shut-down in parts of the country to conserve energy. When the windows are opened it becomes clear why expensive new buildings in the city are usually air-conditioned glass boxes. Not only does the wind blow in a lot of dust (many roads in the city are not tarred); it is also not very practical working with fragile documents when it is breezy. While parts of the building were refurbished a couple of years ago, the search room remains as it is. Thus in today's environment these buildings are outdated in terms of their underlying assumptions and their design features, nevertheless they are ubiquitous in major West African cities, and the fact that they are still in use illustrates their importance, especially considering the failure to replace them with new architectural solutions. The legacy of the independence-era modernism is hard to avoid during fieldwork in major West African cities.

Archival resources in Ghana were not particularly helpful in establishing the rationale behind the widespread adoption of modernist architecture in public and private construction projects in the 1950s and 1960s, but I was aware from prior research at corporate archives that UK-based multinationals retained rich material on their buildings across the world. Archival and historical research is still rare in organization studies (Mills and Helms Mills, 2011; McKinlay, 2002; McKinlay, 2013; Schwarzkopf, 2012), partly a result of the failure of historians to adequately describe the methods they employ (Bernardi and Greenwood, 2014). Rowlinson et al. (forthcoming2014) have argued that archives are underused resources for organizational research, and propose four strategies by which historically informed research could contribute to the development of organization theory. Of these four, the ethnographic approach to organization history best reflects the research strategy employed here. Ethnographic history treats archival sources as texts for the interpretation of culture, seeking to gain an impression of "what it was like to be there" (Stone, 1979: 14). Thus texts are not used to report on the issues that they were ostensibly written about, but rather what they tell us about commonly held assumptions and intentions. Ann Stoler goes even further in her postcolonial approach to the archive: 
"I ask what insights into the social imaginaries of colonial rule might be gained from attending not only to colonialism's archival content, but to the principles and practices of governance lodged in particular archival forms. [...] The [...] focus is on archiving-as-process rather than archives-as-things. Most importantly it looks to archives as condensed sites of epistemological and political anxiety rather than skewed and biased sources (Stoler, 2009: 20)."

Methodologically, this article employs this-archival ethnography as its main research strategy. Archival ethnography is often influenced by postcolonial theory, which has reinforced the importance of explaining the existence or the absence of the evidence that is found in an archive (Trouillot, 1995: 48-49; Spivak, 1988). This theoretical position requires a careful assessment of what kind of archive one is dealing with, and in how far the structure of the collection and the location of sources permits one to draw conclusions about the structure and intentions of the organization (Decker, 2013; Stoler, 2009: 9-10, 20).

In order to understand this kind of research it is important to realise that working with an archive is not as straightforward as visiting a library. Due to the enormous size of many archives, a lot of this material is not digitised, much of it is unique in that they are the only copies in existence, and they can only be consulted in special on-site search rooms. There are different types of archives, some are publicly accessible such as the National Archives, others are privately owned, such as many corporate archives. These may be held by the firm itself, or deposited in public archives, but not necessarily open to the public. All three collections used for this research are privately owned, two are managed by the companies themselves (Barclays Bank and Unilever), while the Standard Chartered deposit was, at the time of my research, managed by the Guildhall Library in London (Manuscripts Section) but has now been transferred to the London Metropolitan Archives. As the copyright of the material lies with the companies or their legal successors, I had to negotiate access to these files in advance, as is the case for to any other research based within the organization. Like 
most public archives, these companies have chosen to withhold access to their archives for a thirty year period, meaning that only documents older than this can be consulted by researchers. Moreover, final versions of articles usually have to be approved by the archivists (Unilever and Barclays), or the company secretary (Standard Chartered). In order to ensure that this does-did not cause any problems or delays, I provided them with copies of the revised drafts whenever I submitted them to the journal as a courtesy. There were no changes requested by the archivists or the secretary other than correcting archival reference numbers or legal terms. ${ }^{3}$

This type of large corporate archive is rarely organised in a very accessible way for any given research project, because research usually revolves around concepts and ideas that are unknown at the time the archival sources were produced (Jordanova, 2006: 38). While it is relatively straightforward to find pictures of company buildings, it is more difficult to identify where architecture was discussed by staff or management, and references to their construction programme was found in very different places. Stoler (2009: 9-10) summarised this succinctly when she concluded that an interest in certain research topics "gets you nowhere, unless you know how they mattered to whom, when, and why they did so." Researching several archives for the purpose of comparative study can be challenging, because these collections reveal idiosyncratic patterns of organization, documentation and communication within different firms (Decker, 2013: 168). As a result, the kind of information suitable for comparison may be found in different locations across archives, and be of a different nature. This means that in archival research, it is important to know how a collection is structured in order to understand where relevant material may be found. Hence identifying this material was sometimes quite serendipitous, for example other researchers pointed me towards documents that they had come across and at times retained for me.

The difficulties of conducting a focused search for relevant material however could bear unexpected fruit in the shape of what I call a "dissonant source", reminiscent of Stoler's recounting of experiencing a jolt when discovering a source that reinterpreted the dominant narratives (Stoler, 
2009: 181-185, 252). An example of such an archival encounter is the story of a hated manager who was excluded from an important branch opening. I had actually found a letter of complaint by this manager during a previous research trip for another project, but discarded it because at the time I did not understand its significance (and was not yet interested in architecture). Today it is impossible for me to remember in which of the many folders that I leafed through this letter might be found, and it would probably take me a week in the archive to find it if I really needed to. Hence experience in archival research teaches one to take copious notes on anything that looks like it may remotely be of interest at some point in the future, and to keep an open mind as to when another document might provide an explanation for a letter that one cannot quite interpret at first. It also explains why archival references are long and complicated, as they provide the only way to pinpoint the proverbial needle in a haystack.

Depending on the size of the archives, this type of research can become a life-filling occupation, and in the case of the largest company collection on West Africa (the UAC files, which form part of Unilever's archive) it would be impossible to claim to have consulted all of the potentially relevant material. In this case I focused my research on Ghana, to get a more complete picture of the activities in one territory. Hence archival ethnography shares some essential features with the more standard ethnographic techniques - one cannot ever be certain to have observed (or consulted) everything, and there are no straightforward techniques to sample or survey the relevant material. Furthermore, it is important to reflect on why material exists on some topics at all: neither the colonial buildings, nor the subsequent, more postmodern or mock-colonial constructions, were accompanied by such an extensive production of brochures, photographic collections and other public relations activities as was the case for modernist architecture, emphasizing the importance these buildings held in the minds of their creators.

Another similarity is that this type of research also requires a deeper immersion in the material, which facilitates a better understanding of the historical context, and an appreciation of the 
otherness of the past. In this case, not only did I conduct my research in foreign countries, the combination of a visual with an archival ethnography also opened my eyes to how differently these buildings were interpreted then and now. In the 1950s and 1960s, they were seen as beacons heralding a brighter future. Most African economies more or less collapsed in the 1980s, and the social and political problems created by extreme poverty have remained central problems for African countries in the 2000s. Thus seeing these buildings today, some refurbished while others are weather-worn, makes one almost nostalgic for a more optimistic age in which many West Africans could hope that the next generation would lead largely middle class lives. Reading company archives makes it clear how widespread this aspiration was, and how seriously foreign firms engaged with it. An archival ethnography allows buildings to be researched in the context of their creation, and reveals multiple layers of meaning which can be reconstructed on the basis of material that survived as well as memoirs that recount events from the past.

\section{Modernist architecture in Ghana and Nigeria}

Modernist architecture was one of the most widespread and influential architectural styles in the middle of the twentieth century. Also called the "International Style", it was uniquely successful in transcending boundaries of space, time, culture and political systems. However, to assume $\overline{\bar{T}}_{\bar{T}}$ that modernism would be interpreted in the same way in different context is a highly unlikely proposition for anyone familiar with the historical context.

Modernism as an architectural movement sought to strip down any embellishments and focus on the kind of form that most supported the intended function of the building. Yet this maxim "form follows function" led to a very specific and easily recognizable visual aesthetic. Building materials were predominantly glass, concrete and metal. The old axial symmetric design of, for example, colonial buildings was replaced by geometric repetition that allowed architects to create much larger edifices. These mostly rectangular designs were frequently raised on "pilotes", square concrete pillars, which created roofed public spaces. Leading architects of the movement, such as Le 
Corbusier, combined their designs with a strong social engineering mentality that sought to create better living conditions in urban areas. Instead, in many countries the social housing projects of this era subsequently created an association between modernism and urban decay. Scott (1998: 85-146) heavily criticized the authoritarian nature of twentieth century high modernism, and the work and vision of Le Corbusier in particular. His "gargantuan schemes" (Scott, 1998: 103) remained mostly unrealized, save for Brasilia (Brazil) and Chandigarh (India), both cities in relatively new states headed by political elites that were committed to social transformation through an authoritarian program of societal modernization and renewal. The appeal of modernist architecture in postcolonial states was heavily predicated on a political commitment to achieving "modernity" against the backdrop of a "traditional" and "backward" society (Deutsch et al., 2001). The widespread adaptation of tropical modernism emphasizes how widely accepted these simplistic ideas once were, and how public organizations, commercial enterprises and private individuals displayed just how modern they were through the buildings they constructed.

Modernist architecture, unfortunately, seemed curiously unsuited to tropical conditions: large windows without shading structures were impractical in the sun and the heat, concrete was an expensive building material, metal corroded in the humidity, large enclosed spaces with low roofs became sweltering ovens. Tropical modernism adapted the aesthetic of modernist architecture but retained the functional features of the better adapted colonial style. Now louvered windows (consisting of horizontal glass panes that can be opened and closed) allowed a cooling draught in buildings that were angled for maximum air circulation and minimum sun exposure (copied from colonial architecture). This was achieved by creating long shallow buildings with overhanging roofs, sometimes raised on pilotes to allow for effective cooling. Instead of shutters, windows were often fronted with "brise-soleil" or sun breakers, which are sun-shading structures that are angled to reduce light and heat exposure. Although brise-soleil increased the energy efficiency of a building, they were in fact quite expensive, and distinctive of the tropical modernist style (Uduku, 2005: 7). ${ }^{4}$ 
These features were first tested in a number of signature post-war government edifices, which served as models of tropical modernism in the region (Cubitt, 1956; Fry, 1953).

Thus the major shift in corporate building styles that occurred in the 1950 s could be viewed as simple imitation. But this is implausible for two reasons: those companies that showed significant building activity with a distinct stylistic departure first opted for another, less radically different style, known as colonial urbanism, which had been developed in the interwar period (Wright, 1991). Colonial urbanism sought to retain important elements of colonial architecture, but fuse it with elements borrowed from traditional, or vernacular, architecture. It was visually reminiscent of Art Nouveau and Art Deco buildings in Europe, some of which included some more geometric elements but retained a basic notion of symmetry to balance an architectural design. Only towards the mid- to late 1950s did companies fully embrace tropical modernism in their construction activity, much later than the major public building projects.

From archival research it is clear that in all three cases, the companies paid great attention to their architectural expression: buildings were opened ceremoniously, portrayed in company magazines and paid-for newspaper reports, annual reports and accounts, corporate histories, mentioned in speeches, photographed frequently and embedded in advertising campaigns or indeed architectural brochures. There were some differences between the kind of activities and the type of materials the banks produced and those that the Unilever-owned United Africa Company (UAC), a manufacturing and retail enterprise, left behind. The next section will discuss how Barclays Bank DCO and the (Standard) Bank of West Africa presented their construction activity, followed by an analysis of the archival material from the UAC.

\section{Modern architecture and the imperial banks: Barclays Bank DCO and Standard Bank of West Africa}

The following section discusses the two cases of the imperial banks, partly as a result of the curious gaps in their archival records. Barclays' archive, held by the company, is in general more complete 
than the deposit made by Standard Chartered. However, the Standard Bank of West Africa collection contains a photo album of branches as well as newspaper clippings of a branch opening in 1968, while newspaper reporting was not found at Barclays's archive. For Barclays, some photographs were available, but many pictures were identified in the Annual Reports and Accounts statements. From the archival records it is clear that the two major banks were rivals, watched each other's activities closely, and extensively copied the other in their public relations and their attempts to gain customers. Thus comparable material probably failed to survive, but may have existed at some stage (Decker, 2013: 163-166). This is commonly the case for companies operating in Africa, especially as many files probably originated in subsidiaries, which were not equipped for professional records management, and likely only transferred surviving documents at the express request of the metropolitan headquarters.

Both banks showed a significant shift in their branch architecture around the time of decolonization. These shifts have been associated in other contexts with a changed conception of money (McGoun, 2004; Frandsen et al., n.d.: 3-4, 10-11). Before colonialism, West Africa used a variety of currencies, for example cowrie shells. With colonialism came the imposition of a foreign currency and paper money, which was initially resisted, and cowrie hoards were frequently buried to hide them from colonial officials. Once the new currency became accepted, this hoarding tradition continued with colonial money, as few inhabitants used banks (Standard Bank of West Africa, 1968). Indeed, West Africa had one of the lowest density of bank branches in the entire British Empire, and mostly served expatriate commercial and private interests (Newlyn, 1952: 450). Unsurprisingly, all branches from this time period, up until the 1950s, were built in the colonial style, considering their audience and the fact the money itself was colonial as well (Black, 2002).

With the Second World War came a change in the role of finance and financial institutions, as there was now an attempt to reinvigorate imperial connections through developing colonial economies. Money was no longer extracted, but also injected into the financial system. It was however clear that 
more capital would have to be raised domestically, through savings and investment. Due to the 1950s boom in raw materials, West African colonies were indeed money-rich for a time. Hence political and commercial interests converged on a savings drive, which aimed to get new parts of the population to use banks for the first time_(Decker, 2005) [Reference to author removed]. In 1968, the Standard Bank of West Africa (the successor of the Bank of West Africa), made its involvement in the major changes that monetization had brought to the region explicit:

"Before the establishment in 1897 of a branch of the Bank of British West Africa (now the Standard Bank of West Africa) which is the first commercial bank that emerged in the Gold Coast (now Ghana), Ghanaians hoarded currency by burying it in the ground [...]. This habit of hoarding money impoverished Ghana. [...] When the Standard Bank of West Africa was established in Ghana, it was faced with the task of breaking the poor saving habit that Ghanaians had cultivated." (Standard Bank of West Africa, 1968)

This is a good example of what Boje calls a chronotope: a temporal narrative that embeds an organization within society. As a result the number of bank branches in the territory increased rapidly: in Ghana, Barclays had eleven and the Bank of British West Africa eighteen branches in 1953, compared to 58 and 29 respectively in 1967, and in Nigeria Barclays branch numbers rose from 18 to 80 and BBWA's from 22 to 68 in the same time period (Decker, 2006, pp. 112-117)[Reference to author removed]. This increase was fuelled by increased opportunities, a changing business model and a high level of competition among banks, which were building new branches across the region.

Figure 1 about here

Due to the extent and the general decentralization of the banks construction activity, their branch building programs are ideal to pinpoint the shift towards modernism over time. They embarked on 
substantial construction projects following the colonial urbanist style at a time period when the radically modernist design of some new government projects, such as hospitals and universities, was much debated (Fry, 1953: 9; Uduku, 2005). A particularly striking example of this style was Barclays Bank's new branch in Kano (figure 1), the main commercial hub in Northern Nigeria. The symbolic importance of this branch for the bank was underscored by the fact that it was frequently mentioned $_{: j, j}$ for example in an unpublished draft for the Bank's history (Barclays Bank DCO, several Fars) and in \pm The (equallyunpublished + memoirs of a former managing director (Barclays Bank DCO, undated 1), for example,- Both-highlighted the architectural style, specifically the corner "feathers" or "horns" that were intended to reflect vernacular architectural features specific to Nigeria's Northern region (figure 2). Gwendolyn Wright (1991) has argued that colonial urbanism in French colonies constituted an attempt to aesthetically fuse elements of European and indigenous architecture, and that it formed part of an attempt to modernize and invigorate the colonial presence in the 1930 s and 1940 s.

Figure 2 about here

The Standard Bank of West Africa also built important branches in the colonial urbanist style, such as its head office in Lagos, Nigeria, of which only photographs survive (figure 3; Bank of West Africa, several years; Bank of West Africa, undated). Barclays head office in Accra was also constructed during this period, but neither referenced vernacular architecture in quite the same way as Barclays' Kano branch did. This reinforces the special status of the Northern Nigerian branch within Barclays' organizational structure.

Figure 3 about here 
From the mid-1950s onwards, however, all new corporate buildings had abandoned colonial urbanism for a more resolute tropical modernism, whose visual expression included neither reference to the colonial past, nor made any visual concessions to African art or cultural representations (at least initially). Given the common associations with these two styles, political context is key in explaining this decision on the part of the companies to switch styles yet again. While trading companies like $t$ The UAC and the banks had understood sincerealized in the late 1940s that they were viewed unfavourably as part of the British colonial presence ${ }_{. ;} \neq \underline{T}$ They initially thought that this would require them to reform their business practices in terms of including African interests better, but still essentially remain imperial companies (Stockwell, 1995). Thus Barclays Bank chose to abbreviate its name from Dominion, Colonial and Overseas to DCO in 1954. Its rival the British Bank of British West Africa renamed itself Bank of West Africa in 1957 and after a merger was renamed again to Standard Bank of West Africa in 1965.

Figure 4 about here

Barclays abandoned colonial urbanism as a stylistic choice shortly after its much discussed Kano branch opened. Their Annual Report of 1954 included a picture of a striking white box on Obun Eko Street on Lagos Island (figure 4), which stands out between the other colonial edifices. However, it differs stylistically from later branches, because it is still quite a closed building with few windows. Most importantly, the "Dominion, Colonial and Overseas" remains very prominent, despite the banks decision to abbreviate this to DCO at about the same time. ${ }^{5}$ This is also true for the Bank of West Africa's Lagos head office, which dates back to the same time, and still features the bank's colonial name (figure 5). By 1960, an image of Barclays' branch at ljebu-Ode (figure 6) was already described as representative of their new style of buildings: the branch showed several elements that are typical of tropical modernism: long, shallow buildings that minimize sun exposure and maximize air circulation through brise-soleil and louvers, while maintaining the modernist idiom of 
transparency and geometric regularity that denoted a sense of openness and functionality (Le Roux, 2004: 7). Interestingly, the BWA's corporate history (Fry, 1976: 194-197) suggested a determined shift towards tropical modernism, completely omitting its flirtation with colonial urbanism. This may reflect the radical political climate of the 1970s, when their rhetorical history was produced (Suddaby et al., 2010b).

Figure 5 about here

Figure 6 about here

Branch opening ceremonies were important social events, and the novelty of architectural expression could be seen as a symbolic reference to a change in management practices. That this was not just something significant for public relations, but also affected the relationship to the banks' workforce is again illustrated by what happened to Barclays' new branch at Kano. Hand in hand with the drive to expand bank branches came the establishment of tighter control in the early 1950s which challenged the considerable autonomy of the old guard of branch managers, known within Barclays as "old coasters". These tensions were not always acknowledged by senior management (Barclays Bank DCO, undated 1). Unsurprisingly the following tale of the opening of Kano branch was not remembered in any official corporate history, but comes from the unpublished memoirs of an expatriate banker:

"The first Local Director, called Cox, was no diplomat and made a difficult situation worse by personal tactlessness; he met his come-uppance, however; in 1952 the important branch at 
Kano, in Northern Nigeria, was due to move into huge, brand new premises, and all arrangements were made to hold a splendid official opening ceremony to which the Governor and most of the local Emirs were invited; Cox, as Local Director and senior Barclays man in the country had naturally arranged to officiate, but when he arrived in Kano to perform his duties, he was sheepishly told that the ceremony had actually taken place the day before. Donald Greenway, the Kano manager, was personally powerful enough to be able to get shaky "explanations" accepted and to ride out the ensuing blasts, but it did the status of LHO [Local Head Office in Lagos] no good at all. News spread on the grapevine like wildfire and all the branches had a huge laugh at the expense of this johnny-come-lately LHO. For years after, relationships between staff in branches and staff in LHO were gravely soured by an unpleasant "them and us" mentality." (Barclays Bank DCO, undated 2)

The new architecture clearly communicated the need for organizational change not just to the bank's customers and political networks, but on occasion it also made these new branches the focus of internal dissent.

New bank branches also did not magically create legitimacy for controversial firms, and the banks' colonial past would still get referenced amidst the narratives of economic development and a glorious future. In the obviously paid-for journalistic coverage of the opening of the new Accra head office of the Standard Bank of West Africa, there is a reference to the bank "extending its tentacles" throughout West Africa, in what is otherwise a glowingly told rhetorical history. The same article highlights that the bank is the oldest in the territory, which to informed readers may have alluded to the bank's status as a monopolist until Barclays' predecessor arrived in 1916. There is also a reference to its lending and bad debts that dated back to the late 1950 s - an embarrassingly unsuccessful public relations-driven attempt to mitigate political pressure (Decker, 2005[reference to author removed], Uche, 1998). However, these were exceptions, and the overwhelming amount 
ofmostly companies' corporate narratives surrounding their buildings told very similar storiesremained oriented towards the future, often at the expense of their past.

Figure 7 about here

Anteby \& Molnar (2012) have argued that remembering to forget is important for the maintenance of organizational identities over time, but it is even more so when collective memories are under pressure to change. Internally and externally, practices, narratives and visual identities were adapted to the conditions of the decolonizing states and their desire for progress, as embodied in modern conveniences such as bank branches with drive-in facilities (figure 7), or in the case of the UAC internal features such escalators (United Africa Company, 1956) and passenger lifts (United Africa Company, 1962b) which were a novelty in West Africa. These new spaces offered credibility for the narratives of development, as well as environments for the new middle classes to envisage themselves as thoroughly modern. However, West African societies and imperial business elites did not actually develop a case of intense yet entirely partial amnesia. Memories shifted only slowly, but this made the ambiguity of architectural interpretations so appealing.

Of the three companies, only Barclays did not produce any brochures or had any media reports of their branch openings in their archives, but a memorandum from their public relations committee from 1957 proposed an "exhibition of DCO premises as a means of illustrating the Bank's widespread activities and contributions to the Commonwealth" (Barclays Bank DCO, undated 4), indicating that the bank's management was aware of the public relations potential of its branch building programme. Its annual reports regularly featured images of their branches around the world, and West African branches were displayed nearly every year. The visiting reports by managers from London regularly discussed premises, and some speeches from opening ceremonies survived. 
The narratives and representations of buildings were not the only way firms employed architecture. These spaces were also used to foster better relationships with the new elites, most notably through formal opening ceremonies, which were invariably attended by high-ranking politicians and local chiefs. Thus Julian Crossley's 1959 speech at the opening of the new High Street head office needs to be viewed as an oratory in front of an elite audience of politically significant future contacts:

"But, gentlemen, this is something much more than a building. It is the solid proof of our confidence in the future of your country - and when people ask me, as they sometimes do "Well, what do you people in Barclays think of the future of Ghana?" I simply point to this building. It saves me a lot of words and, of course, it is deeds rather than words that carry conviction." (Barclays Bank DCO 9)

Buildings were interpreted by their owners, and used not just as a form of communication, but as means to engage in conversations about the future rather than the past.

\section{The United Africa Company - A controversial monopolist or a pioneering} retail enterprise?

The United Africa Company was by far the largest company operating in the region, controlling over half of the West African trade in the late 1940s (Bauer, 1954: 99). As a result, the firm was singled out for significant criticism and attack. The name UAC was colloquially used to refer to very old and rich prostitutes, and was moreover associated with witchcraft (Murillo, 2011: 29). Although West African societies put great emphasis on "symbolic displays of achievement" (Le Roux, 2004: 371), it was the close association of these British companies with the colonial empire, and their practice of extracting wealth without developing the countries in which they operated that was deemed unacceptable. The firm's construction activity, however, was considered a socially desirable way of showing wealth and importance, and created opportunities for networking.

Due to its size, its bureaucratic organization, and its controversial nature, the UAC's public relations and construction activity was second to none, and its archival collection reflects this by its sheer 
scale and level of detail. It would be improbable to claim that it was possible to find all references to architecture in this sizeable collection; what is certainly clear is that it was deemed important for its internal and external communication. In contrast to the decentralized construction activity of bank branches, the UAC repeatedly referred to a core set of iconic buildings. It was the only company that dedicated a brochure to its architectural achievements. Due to the size of the archive, I decided to focus more on researching some of the prominent buildings in Accra that I knew and that still existed, as they were clearly used as iconic representations by the company. Moreover, the Ghanaian public was more nationalistic and critical of foreign firms in the 1950 s and 1960 s than the Nigerians, and regional rivalries were less important in the much smaller country so that construction activity focused mostly on Accra and a few major cities.

Figure 8 about here

The company built two major and important edifices in Ghana's capital one in the late 1940s, the other one in the mid-1950s, which show the same shift from colonial urbanism to tropical modernism as in the case of the banks. The first building was its corporate headquarters (figure 8), later described as a "forerunner" of the corporate building program and quite a neutral example of colonial urbanism (United Africa Company, 1962a). However, its outdated facade was later 'cloaked', presumably at some point in the late 1960 s or early 1970 s, by refitting it with vertical brise-soleil which covered its entire frontage (see figure 9). This was not an uncommon visual feature in the urban context of Accra, where some governmental buildings had very similar frontages. In the 1970s, an image of the refitted Swanmill was used in an advert promoting the company's activities (figure 10). This building was emblematic of the shift in architectural styles that the UAC's construction drive underwent.

Figure 9 about here 
The Swanmill is also interesting as an example of "forgetting the past". The company newsletter in its reporting on the opening of the building in 1950 referred to a "burnt store" which the Swanmill replaced (United Africa Company, 1950). To the readers of the company magazine this oblique reference should have been of immediate significance as a reference to the 1948 Gold Coast riots, but subsequent discussions of the firm's construction activity never mentioned this again. The riots followed a boycott of foreign trading companies at a time when the price and availability of merchandise meant that it had become inaccessible for large parts of the population. In the looting and destruction that ensued, the UAC was noticeably singled out as a target (John Holt \& Co, 19481953). In response, the company committed itself to a review and subsequent changes to its business practices (Fieldhouse, 1994: 337-343) but political pressure led the firm to retrench its significant network of stores and agents, and focus on wholesale and related activities, as well as the upmarket Kingsway department stores (Decker, 2007: 109-112; Murillo, 2012). Hence both symbolically and physically (at least in the case of Swanmill) these new buildings replaced the old corporation that had been too colonial. Some examples of colonial urbanist shop premises have however survived, such as the administrative block on Jackson Street, Cape Coast (figure 11), completed in 1951, which is still in use today and doubles up as rented shop premises and advertising space, a common practice in West African cities (figure 12).

Figure 11 about here

Figure 12 about here 
The company's other major construction was the Kingsway Department Store, opened in 1957, the year of Ghana's independence, and this was a distinctive and uncompromisingly modernist building (figure 123). As a department store, it offered a self-contained consumption space that did not have many equals in the capital, and counted the first president of Ghana, Kwame Nkrumah, as one of its customers (Murillo, 2010: 11). Even though there were only seven years between the openings of these two landmark buildings in Accra, their stylistic references are clearly very different. The Swanmill, for example, still featured wooden interior décor with the company's unicorn logo (figure 134), even though the UAC abandoned it in its visual communications in favour of a much starker and geometric sign. Kingsway, in contrast, became renowned for its modern shopping experience and service, and its role in creating the modern "African consumer" (Murillo, 2012: 371, 376-377) made it a very special elite urban space.

Figure 123 about here

Figure $1 \underline{3} 4$ about here

Considering the prominent position that the UAC held in the commercial life of these African countries, management was not going to rely on the potentially ambiguous interpretations of its architecture, but chose to embed the images of its flagship buildings in powerful corporate narratives of modernisation (Barthes, 1977). The UAC, for example, frequently published images of its buildings in its internal newsletter, in the press, and even created a brochure on its architecture for Ghana entitled "Buildings speak..." which revealed a certain diversity of architectural styles, even 
though examples of modernism were most common. Most commonly-corporate narratives conveyed one message again and again - the intention to stay:

"There is an aura of confidence about a big, solid building which in turn inspires confidence in the beholder. If it is a dwelling house it tells in ringing tones of the owner's firm resolve to settle in that place and to become a man of consequence in the locality." (United Africa Company, 1950)

Figure $14 \underline{5}$ about here

Claims of confidence and permanence have to be seen in the light of considerable challenges to the legitimacy of these firms, considering how closely they had been identified with colonialism in West Africa. However, a more common narrative ploy was to claim antiquity to reinforce a business's place in society, a practice highlighted by Rowlinson et al. (2010: 82-84). In one of its adverts, the UAC made reference to its 250 year history in the region. This is a remarkable claim, because the oldest predecessor of the UAC, the Royal Niger Company, only dated back to 1879 . The reference may mistakenly refer to the Royal Africa Company (1660-1752), which was involved in the slave trade. This sits uneasily with the image depicting the symbolic replacement of a traditional market scene with a modern department store building (figure 1544). But just like the banks, the UAC ultimately returned to highlighting its sheer financial might, embodied in the solidity and scale of its construction activities:

"By the magnitude of its investments in West Africa the Company proclaims its undiminished faith in the future of the countries with which it is so closely identified." (United Africa Company, 1962a) 
The other recurring theme was that of the future, and the companies' intention of contributing to a vision of a thoroughly modern and developed Africa. These historical narratives of progress and development are common for many mnemonic communities, according to Zerubavel (2003: 14-16). Boje (2008) highlights another further-use of temporal narratives: chronotopes that insert corporate memory into the wider national history, which sought to gain legitimacy for its social and economic position, a practice also discussed by Foster et al, (2011). These parallel stories of advancement are particularly obvious in the following excerpt:

"Progress in one respect is seldom unaccompanied by progress in another [...]. Marching in step with this development in housing and public buildings come the commercial firms. The business house which identifies itself with the future of the people who are its customers demonstrates its confidence [...] by investing large sums of money in erecting permanent buildings which symbolize enterprise and prosperity not for the present only, but for the future. The pioneer amongst commercial firms in this as in other fields of activity has been The United Africa Company." (United Africa Company, 1962a)

Kwame Nkrumah, for example, frequently attended these events, including the opening of the new Kingsway Store in Accra in 1957, in which he was a regular customer (Murillo, 2011):

"The atmosphere in which the celebrations had taken place was one of brilliance and good humor, and Dr. Nkrumah had taken the opportunity of paying a tribute to the efforts made by the United Africa Company over recent years, and his belief in the part the Company had to play in the future." (Unilever, 1957)

Nkrumah seemingly echoed the same kind of language as the UAC, as well as referencing the firm's efforts to develop the country and reassuring the management that their company would be welcome in the future. One of the UAC's chairmen suggested in his memoir that these events appealed to politicians like Nkrumah, because he wanted to "associate himself with these ocular 
demonstrations of development" (Pedler, 1989: 20). Hence the frequent references to the 'solidity' of their confidence reminded audiences that these formerly imperial companies were now investing large sums in highly prestigious buildings and were seeking a new relationship with erstwhile colonial subjects. Their changed business practices were in response to their vision of a West Africa very different from the one they had known before. It was this imagined future that determined managerial decision-making more than what actually came to pass (Batiz-Lazo et al., 2011).

\section{Conclusion}

Even though the architecture itself does not change, the world that surrounds it does, and with it the communities that give it meaning. Space does not always stabilize time, indeed it is often used reinterpreted to contort or accelerate-temporality, as the mnemonic practices of British business in West Africa show. Corporate attempts to influence the narratives on which mnemonic communities sought to create a changed understanding of their society are not unique to West Africa in the middle of the twentieth century. Archival research permits insights not just into history, but also into changing forms of social remembering. These collective memories are formed through encounters that take place in spaces, whose design and layout can facilitate or obstruct connections between different sets of people. In the end, however, it is precisely the shared understanding of a building that gives it meaning, which is communicated across space and time through collective memory and history. Without it, we cannot understand the meaning of the architecture that surrounds us. Yet accounting for the shifting and heavily negotiated meanings of organizational practices can be difficult to accomplish with existing research methods such as interviews and participant observation. Organizational archives offer important insights to critical organization scholars through archival ethnography and other historical research techniques, which have yet to find widespread acceptance in this area. Hence this article contributes to a slowly-growing body of scholarship in management and organizational history (Rowlinson et al., 2014) by demonstrating the potential uses of an archival ethnography informed by postcolonial theory. 
The second contribution is to highlight that the spatial turn in organization studies has at times assumed that space is unrelated to temporality. In line with recent calls to focus more on the experience of space, tThis research argues that any experience of space is deeply embedded in time, and that this allows architecture to point not only to the past but also to the future, depending on the kind of narratives and practices that resonate in collective memories.

The complex ways in which buildings can allude to past events and hopes for the future aspirations defies simple Eategorisationcategorization. and modernist architecture is a particularly interesting example due to the political mobilization of a utopian vision of ideal communities that permeated architectural discourse. Narratives of modernization were equally widespread at the time, and the visual language that resolutely eschewed any kind of antiquarian references fitted these chronotopes, or temporal narratives, particularly well. Moreover, it was the "International Style", which offered new African states a sense of participating in a global "modernity" - something that educated Africans were conscious of having been excluded from during colonialism. Hence, by conforming to the tropical modernist style which began to dominate hospitals, schools, embassies and government offices from the 1950s onwards, companies visually demonstrated mimetic and normative compliance with the nationalist development agenda.

Thus it is too simple to just view buildings as an expression of a vague notion of zeitgeist - instead architecture achieved meaning through the organizational remembering that evolved around these buildings and that management sought to influence. The ways in which these companies claimed to contribute to economic development were not always directly observable: changing financial habits or consumptions patterns, for example, were the kinds of business activities that defied straightforward representation (Berg and Kreiner, 1990). Hence "something had to say that something was different" (Frandsen et al., n.d.: 35). Here architecture fulfilled a symbolic function when significant changes in practices, routines and relationships could not be made visible, and when the value-adding activities that occurred within firms were largely intangible. 
Importantly, the size, expense and novelty of the buildings themselves were used as distinct messages in their own right, highlighting the companies' investment and their intentions to maintain their prominent economic positions despite the end of colonialism, but in a socially legitimate way. For the companies that created these buildings, they were a visual, physical record of changed organizational practices. Moreover, they symbolized that companies were receptive to the demands of the countries they operated in, and created occasions to celebrate and connect with the aspirations of the new elites. The opening of bank branches, headquarters, factories or department stores served as symbolic beginnings to narratives of corporate goodwill and cooperation. This new chapter in the relationship between multinationals and host countries proposed to leave colonialism behind by focusing on the future.

In a country with an overwhelmingly pro-Western leadership like Nigeria's first republic, there were no major challenges to foreign companies participating in a modernizing discourse that suited competing nationalist agendas. Remembering to forget the colonial past was less certain in Ghana, where in the late 1960s even paid-for newspaper reporting could contain occasionally critical remarks. Here the political climate during Kwame Nkrumah's tenure (1952-1966) had been much more radical and pro-socialist. However the fact that Nkrumah was keen to attend and be associated with the opening of new corporate buildings and factories was testament to the wider social memory-shaping potential of buildings that served to embody stories of development and progress, irrespective of the often tetchy relationship between business and politics in those years. This emphasizes how important organizational remembering can be as a resource to restructure firms' external relations (Foster et al., 2011). Thus not only could architecture and the use of space be linked to the narrative construction of organizational remembering, but it offered a uniquely effective way to create emotional and-affective connections to social aspirations that often superseded more critical attitudes. 


\section{References}

Anteby M and Molnár V. (2012) Collective Memory Meets Organizational Identity: Remembering to Forget in a Firm's Rhetorical History. Academy of Management Journal 55: 515-540.

Arnhem R. (1977) The Dynamics of Architectural Form, Berkeley, Los Angeles, London: University of California Press.

Bank of West Africa (several years) Collection of Annual Reports and Accounts for Bank of West Africa, later Standard Bank of West Africa, Standard-Chartered Archives on loan to the London Metropolitan Archives [LMA] Ms28,517.

Bank of West Africa (undated) Photo album, LMA Ms28,804.

Barclays Bank DCO (several years) Collection of Annual Reports and Accounts for Barclays DCO, Barclays Group Archives [BGA] E244.

Barclays Bank DCO (undated 1) Frederick Seebohm's Memoirs, BGA 277/7.

Barclays Bank DCO (undated 2) Memoirs by Hugh Norris, BGA 11/2155.

Barclays Bank DCO (undated 3) Public Relations Committee, BGA 80/4330.

Barclays Bank DCO (undated 4) DCO Operations, Visits by Directors \& Senior Officials, BGA 80/3649.

Barclays Bank DCO (1952) Crossley's trip to West Africa, BGA 80/3792.

Barclays Bank DCO (1952) Photograph of DCO's Kano branch, BGA 38/1284a.

Barclays Bank DCO (1959) Visit to West Africa, BGA 80/4351.

Barclays Bank DCO (1964) Dyson's visit to West Africa, BGA 80/4641.

Barthes R. (1977) The Rhetoric of the Image. Image, Music, Text. Glasgow: Fontana Press, 33-47.

Batiz-Lazo B, Haigh T and Stearns DL. (2011) How the Future Shaped the Past: The Case of the Cashless Society. Munich Personal RePEc Archive.

Bauer PT. (1954) West African Trade: A Study of Competition, Oligopoly and Monopoly in a Changing Economy, Cambridge: Cambridge University Press.

Berg PO and Kreiner K. (1990) Corporate Architecture: Turning Physical Settings into Symbolic

| Resources. In: Gagliardi P (ed) Symbolds and Artifacts: Views of the Corporate Landscape. Berlin and New York: Walter de Gruyter, 41-67.

Bernardi A and Greenwood A. (2014) Understanding the rift, the (still) uneasy bedfellows of History and Organization Studies, Organization.

Beyes T and Steyaert C. (2012) Spacing organization: non-representational theory and performing organizational space. Organization 19: 45-61.

Black IS. (2002) Reordering Space: British Bank Building Overseas 1900-1940. In: Graaf Td, Jonker J and Mobron J-J (eds) European Banking Overseas, 19th-20th Century. Amsterdam: ABN AMRO Historical Archives, 77-108.

Boje D. (2008) Storytelling Organizations, London: Sage.

Brown AD. (2006) A narrative approach to collective identities. Journal of Management Studies 43: 731-753.

Brown AD, Gabriel Y and Gherardi S. (2009) Storytelling and Change: An Unfolding Story. Organization 16: 323-333.

Brown AD, Kornberger M, Clegg SR, et al. (2010) 'Invisible walls' and 'silent hierarchies': A case study of power relations in an architecture firm. Human Relations 63: 525-549.

Burrell G and Dale K. (2003) Building better Worlds?: Architecture and Critical Management Studies. In: Alvesson M and Willmott H (eds) Studying Management Critically. London: Sage.

Cubitt J. (1956) James Cubitt in Ghana. Architectural Review 119: 230-241.

Dale K and Burrell G. (2008) The spaces of organisation and the organisation of space: Power, identity and materiality at work: Palgrave Macmillan.

Dale K and Burrell G. (2010) All together, altogether better: The ideal of 'community'in the spatial reorganisation of the workplace. Organizational Spaces: Rematerializing the Workaday World: 19. 
Decker S. (2005) Decolonising Barclays Bank DCO? Corporate Africanisation in Nigeria, 1945-69. Journal of Imperial and Commonwealth History 33: 419-440.

Decker, S. (2006). Building up Goodwill: British Business, Development and Economic Nationalism in Ghana and Nigeria, 1945-1977. PhD, University of Liverpool, Liverpool.

Decker S. (2007) Corporate Legitimacy and Advertising: British Companies and the Rhetoric of Development in West Africa, 1950-1970. Business History Review 81: 59-86.

Decker S. (2013) The Silence of the Archives: Business History, Postcolonialism and Archival Ethnography. Management \& Organizational History 8: 155-173.

Delahaye A, Booth C, Clark P, et al. (2009) The genre of corporate history. Journal of Organizational Change Management 22: 27-48.

Deutsch J-G, Probst P and Schmidt H. (2001) African Modernities: Entangled Meanings in Current Debate. Oxford: James Currey.

Dovey K. (1999) Framing Places: Mediating Power in Built Form, London: Routledge.

Fayard AL and Weeks J. (2007) Photocopiers and water-coolers: The affordances of informal interaction. Organization Studies 28: 605-634.

Fieldhouse DK. (1994) Merchant Capital and Economic Decolonisation: The United Africa Company 1929-1987, Oxford: Clarendon.

Foster WM, Suddaby R, Minkus A, et al. (2011) History as social memory assets: The example of Tim Hortons. Management \& Organizational History 6: 101-120.

Frandsen A-C, Hiller TB and McGoun EG. (n.d.) Money Reloaded: The Architecture of Trust.

Frandsen, A.-C., Hiller, T., Traflet, J., \& McGoun, E. (2013). From Money storage to Money store: Openness and Transparency in Bank Architecture. Business History, 55(5), 695-720.

Fry EM. (1953) African Experiment: Building for an Educational Programme in the Gold Coast. Architectural Review 113: 298-310.

Fry R. (1976) Bankers in West Africa: The History of the British Bank of West Africa, London: Hutchinson Benham.

Golant BD and Sillince JAA. (2007) The Constitution of Organizational Legitimacy: A Narrative Perspective. Organization Studies 28: 1149-1167.

Guillén MF. (1997) Scientific Management's Lost Aesthetic: Architecture, Organization, and the Taylorized Beauty of the Mechanical. Administrative Science Quarterly 42: 682-715.

Guillén MF. (2006) The Taylorized Beauty of the Mechanical: Scientific Management and the Rise of Modernist Architecture, Princeton, NJ and Oxford: Princeton University Press.

Halbwachs M. (1980 [1950]) The Collective Memory, New York: Harper \& Row Colophon Books.

Halbwachs M. (1992) On Collective Memory, Chicago: University of Chicago Press.

Hassard J and Wolfram Cox J. (2013) Can Sociological Paradigms Still Inform Organizational Analysis? A Paradigm Model for Post-Paradigm Times. Organization Studies 34,11: 1702-1728.

Hess J. (2000) Imagining Architecture: The Structure of Nationalism in Accra, Ghana. Africa Today 47.

Hobsbawm E. (1983) Introduction: Inventing Traditions. In: Hobsbawm E and Ranger T (eds) The Invention of Tradition. Cambridge Cambridge University Press, 1-14.

Hobsbawn E and Ranger T. (1983) The Invention of Tradition. Cambridge: Cambridge University Press.

Humphreys M and Brown AD. (2002) Narratives of Organizational Identity and Identification: A Case Study of Hegemony and Resistance. Organization Studies 23: 421-447.

John Holt \& Co (1948-53) Gold Coast Riots, Rhodes House Library, Oxford University, Mss Afr. $\mathrm{S} 825,549$.

Jordanova L. (2006) History in Practice, London: Bloomsbury.

Kornberger M and Clegg SR. (2004) Bringing space back in: organizing the generative building. Organization Studies 25: 1095.

Kultermann U. (1963) New architecture in Africa, London: Thames \& Hudson.

Kultermann U. (1969) New directions in African architecture, New York: Braziller. 
Kümin B and Usborne C. (2013) At Home and in the Workplace: A Historical Introduction to the "Spatial Turn". History and Theory 52: 305-318.

Le Roux H. (2004) Modern Architecture in post-colonial Ghana and Nigeria. Architectural History 47: 361-392.

Lefebvre H. (1991) The Production of Space, Oxford: Blackwell.

Massey D. (2005) For Space, London: Sage.

McGoun EG. (2004) Form, function, and finance: architecture and finance theory. Critical Perspectives on Accounting 15: 1085-1107.

McKinlay A. (2002) 'Dead Selves': The Birth of the Modern Career. Organization 9: 595-614.

McKinlay A. (2013) Following Foucault into the archives: clerks, careers and cartoons. Management \& Organizational History 8: 137-154.

Mentzer MS. (2010) Scientific Management and the American Hotel. Management \& Organizational History 5: 428-446.

Mills AJ and Helms Mills J. (2011) Digging Archaeology: Postpositivist Theory and Archival Research in Case Study Development. In: Piekkari R and Welch C (eds) Rethinking the Case Study in International Business and Management Research. London: Edward Elgar, 342-360.

Molnár V. (2005) Cultural Politics and Modernist Architecture: The Tulip Debate in Post-War Hungary. American Sociological Review 70: 111-135.

Molnár V. (2013) Building the State: Architecture, Politics, and State Formation in Postwar Central Europe, London: Routledge.

Murillo B. (2010) Commercial Space, Consumer Politics, and the Establishment of Kingsway Department Stores in Accra. Birmingham Conference. University of Birmingham, UK.

Murillo B. (2011) "The Devil We Know": Gold Coast Consumers, Local Employees, and the United Africa Company, 1940-1940. Enterprise and Society 12: 317-355.

Murillo B. (2012) 'The modern shopping experience': Kingsway Department Store and Consumer Politics in Ghana. Africa 82: 368-392.

Mutch A. (2011) Modernist architecture and scientific management: Owen Williams, the Boots 'Wets' building and the importance of practice. Management \& Organizational History 6 : 328-344.

Newlyn W. (1952) The Colonial Empire. In: Sayers R (ed) Banking in the Commonwealth. Oxford: Clarendon Press, 421-460.

O'Doherty D, De Cock C, Rehn A, et al. (2013) New Sites/Sights: Exploring the White Spaces of Organization. Organization Studies 34: 1427-1444.

Olick JK. (2001) Collective Memory. In: Smelser NJ, Wright J and Baltes PB (eds) International Encyclopedia of the Social Sciences. 2nd ed. New York, London: Macmillan, 7-8.

Panayiotou A and Kafiris K. (2011) Viewing the Language of Space: Organizational Spaces, Power, and Resistance in Popular Films. Journal of Management Inquiry 20: 264-284.

Pedler F. (1989) Business and Decolonization in West Africa, c.1940-1960: A Personal Memoir by Sir Frederick Pedler, Oxford: Privately printed with the assistance of generous grants for UAC, Barclays Bank and Mr John Zochonis.

Probst P, Deutsch J-G and Schmidt H. (2001) Introduction: Cherished Visions \& Entangled Meanings. In: Probst P, Deutsch J-G and Schmidt H (eds) African Modernities: Entangled Meanings in Current Debate. Oxford: James Curry, 1-17.

Ranger T. (1983) The Invention of Tradition in Colonial Africa. In: Hobsbawm E and Ranger T (eds) The Invention of Tradition. Cambridge: Cambridge University Press, 211-262.

Rhodes C and Brown AD. (2005) Narrative, organizations and research. International Journal of Management Reviews 7: 167-188.

Rowlinson M, Booth C, Clark P, et al. (2010) Social Remembering and Organizational Memory. Organization studies 31: 69-87. 
Rowlinson M, Hassard J and Decker S. (forthcoming2014) Strategies for Organizational History: A Dialogue between Historical Theory and Organization Theory. Academy of Management Review 39,3.

Schwarzkopf S. (2012) The Market Order as Metaphysical Loot: Theology and the Contested Legitimacy of Consumer Capitalism. Organization 19: 281-297.

Scott JC. (1998) Seeing like a state: how certain schemes to improve the human condition have failed, New Haven, Conn.; London: Yale University Press.

Sillince JAA and Brown AD. (2009) Multiple organizational identities and legitimacy: The rhetoric of police websites. Human Relations 62: 1829-1856.

Spivak GC. (1988) Can the Subaltern Speak? In: Nelson C and Grossberg L (eds) Marxism and the Interpretation of Culture. Urbana, IL: University of Illinois Press, 271-313.

Standard Bank of West Africa (1968) Newspaper clippings of new Accra branch, LMA Ms28,816.

Stockwell SE. (1995) Political Strategies of British Business During Decolonization - the Case of the Gold-Coast Ghana, 1945-57. Journal of Imperial and Commonwealth History 23: 277-300.

Stoler AL. (2009) Along the Archival Grain: Epistemic Anxieties and Colonial Common Sense, Princeton: Princeton University Press.

Stone L. (1979) The revival of narrative - reflections on a new old history. Past \& Present 85: 3-24.

Suddaby R and Foster W. (n.d.) Mnemonic Entrepreneurship: The Visual Rhetoric of Corporate History.

Suddaby R, Foster WM and Trank CQ. (2010a) Rhetorical history as a source of competitive advantage. In: A.C. BJ and Lampel J (eds) Advances in Strategic Management. Bradford: Emerald Group Publishing Limited, 147-173.

Suddaby R, Foster WM and Trank CQ. (2010b) Rhetorical History as a Source of Competitive Advantage. Advances in Strategic Management 27: 147-173.

Trouillot M-R. (1995) Silencing the Past: Power and the Production of History, Boston: Beacon Press.

Uche CU. (1998) Accounting and Control in Barclays Bank DCO: The Lending to Africans Episode. Accounting, Business and Financial History: 239-260.

Uduku O. (2005) Modernist architecture and 'the tropical' in West Africa: The tropical architecture movement in West Africa, 1948-1970. Habitat International 30.

Unilever (1957) Unilever Directors' Committee Meeting Minutes, 29 March, UARM.

United Africa Company (1950) Gold Coast U.A.C. News, Special Swan Mill Number, Vol. 1, No. 7, June, Unilever Archives Records Management [UARM]

United Africa Company (1956) UAC Minute book No. 11, 3 January - 18 December, UARM.

United Africa Company (1962a) Buildings Speak ... UAC Buildings in Ghana, UARM UAC/2/20/7/1/3.

United Africa Company (1962b) Unicorn, May, UARM.

United Africa Company (1971) The United Africa Company in Modern Ghana, UARM $\mathrm{UAC} / 2 / 20 / 7 / 1 / 6$.

van Marrewijk A and Yanow D. (2010) Organizational Spaces: Rematerializing the Workaday World: Edward Elgar Publishing.

Walsh JP and Ungson GR. (1991) Organizational Memory. The Academy of Management Review 16: 57-91.

Whyte W. (2006) How do Buildings Mean? Some Issues of Interpretation in the History of Architecture. History and Theory 45: 153-177.

Wright G. (1991) The Politics of Design in French Colonial Urbanism, Chicago and London: University of Chicago Press.

Yanow D. (1995) Built Space as Story. Policy Studies Journal 23: 407-422.

Yanow D. (1998) Space stories: Studying museum buildings as organizational spaces while reflecting on interpretive methods and their narration. Journal of Management Inquiry 7: 215.

Zerubavel E. (2003) Time maps: Collective memory and the social shape of the past, London: University of Chicago Press.

Author Biødetails: 
Stephanie Decker is a senior lecturer at Aston Business School. As a historian working at a business school, most of her work is concerned with the nexus between the social sciences and history, specifically organization theory and business history. After completing her PhD in history at the University of Liverpool, she held postdoctoral appointments at the LSE and Harvard Business School. Her empirical research focuses on the post-colonial history of sub-Saharan Africa and employs narrative, visual and archival approaches to issues such as organisational change and legitimacy in multinational companies in developing and emerging countries.

Stephanie Decker is a senior lecturer at Aston Business School and has previously held appointments at the London School of Economics and Political Science, Harvard Business School, and University of Liverpool Management School. She researches the history of multinationals investing in Africa and the legacies of colonialism for organizational legitimacy. As some of her research approaches are hardly used in organization studies she has also published on how historical methods and theory can contribute to organizational theory.

\footnotetext{
${ }^{1}$ The edited book on The Invention of Tradition by Hobsbawm and Ranger is a highly regarded work in the | humanities (Google Scholar attributes 12,715 citations) and thus comparable in influence to Glenn-Gareth Morgan and Gibson Burrell's book Sociological Paradigms and Organisational Analysis (7,739 citations on Google Scholar), which was prominently discussed by Hassard \& Wolfram Cox (2013).

${ }^{2}$ Interviews with the architect working for James Cubitt \& Partners took place in Lagos, July 2006, and with the architect from Nixon \& Borys in Accra, August 2006. The latter designed Ghana's national archives building. ${ }^{3}$ I would like to thank the archivists for granting me access to the collection and for their help during my research, especially Nicholas Webb and Maria Sienkiewicz at Barclays Group Archives, and Jeannette Strickland and Diane Backhouse at Unilever Archives and Records Management. The staff of the manuscript section of the Guildhall Library was unfailingly friendly and supportive during my research there. I would also like to thank Suzie Andrews, the Head of Board Operations, the Group Company Secretary and Business Planning Aanager of Standard Chartered Bank, for granting me permission to use their material.

${ }^{4}$ This was also indicated in the interview with one of the architects.

${ }^{5}$ I would like to thank an anonymous conference reviewer for this observation.
} 